\title{
Plant Species on the Department of Energy-Oak Ridge Reservation That Are Rare, Threatened or of Special Concern
}

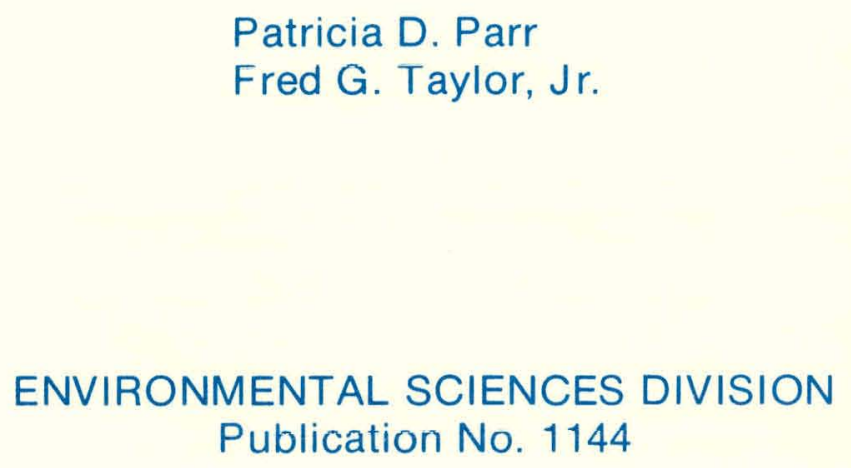




\section{DISCLAIMER}

This report was prepared as an account of work sponsored by an agency of the United States Government. Neither the United States Government nor any agency Thereof, nor any of their employees, makes any warranty, express or implied, or assumes any legal liability or responsibility for the accuracy, completeness, or usefulness of any information, apparatus, product, or process disclosed, or represents that its use would not infringe privately owned rights. Reference herein to any specific commercial product, process, or service by trade name, trademark, manufacturer, or otherwise does not necessarily constitute or imply its endorsement, recommendation, or favoring by the United States Government or any agency thereof. The views and opinions of authors expressed herein do not necessarily state or reflect those of the United States Government or any agency thereof. 


\section{DISCLAIMER}

Portions of this document may be illegible in electronic image products. Images are produced from the best available original document. 


\section{Printed in the United States of America. Available from National Technical Information Service \\ U.S. Department of Commerce 5285 Port Royal Road, Springfield, Virginia 22161 \\ Price: Printed Copy $\$ 4.50$; Microfiche $\$ 3.00$}

This report was prepared as an account of work sponsored by an agency of the United States Government. Neither the United States Government nor any agency thereof, nor any of their employees, contractors, subcontractors, or their employees, makes any warranty, express or implied, nor assumes any legal liability or responsibility for any third party's use or the results of such use of any information, apparatus, product or process disclosed in this report, nor represents that its use by such third party would not infringe privately owned rights. 
Contract No. W-7405-eng-26

\title{
PLANT SPECIES ON THE DEPARTMENT OF ENERGY -OAK RIDGE RESERVATION
}

THAT ARE RARE, THREATENED OR OF SPECIAL CONCERN

\author{
Patricia D. Parr and Fred G. Taylor, Jr. \\ ENV IRONMENTAL SCIENCES DIVISION \\ Publication No. 1144
}

\author{
Date Published - March 1978
}

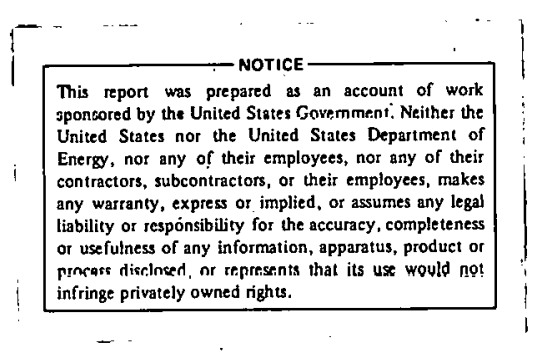

OAK RIDGE NATIONAL LABORATORY

Oak Ridge, Tennessee 37830

operated by

UNION CARBIDE CORPORATION

for the

DEPARTMENT OF ENERGY 
THIS PAGE

WAS INTENTIONALLY LEFT BLANK 


\section{ACKNOWLEDGMENTS}

The suggestions and assistance by Linda Mann and Tom Kitchings in locating rare plants is greatly appreciated. Lynn Tharp of the Computer Sciences Division is gratefully acknowledged for assistance in programming the "Combined Rare Plant List." Appreciation is also expressed to Dr. H. R. DeSelm of the University of Tennessee. 
THIS PAGE

WAS INTENTIONALLY

LEFT BLANK 
PARR, P. D., and F. G. TAYLOR, Jr. 1978. Plant species on the Department of Energy-0ak Ridge Reservation that are rare, threatened or of special concern. ORNL/TM-6101. Oak Ridge National Laboratory, Oak Ridge, Tennessee. $44 \mathrm{pp}$.

The need to protect endangered organisms has gained increased awareness during the past decade. These efforts have only recently been expanded to include plants. Lists of candidate species have been compiled for review and status designation by appropriate governmental actions. The Report on Endangered and Threatened Plant Species of the United States presented to Congress by the Secretary of the Smithsonian Institution (U.S. Congress 1975) recommended that the preservation of critical habitats be adopted as a major management practice to ensure the survival of endangered and threatened plant species.

In compliance with federal guidelines, plants occurring on the Department of Energy (DOE) Oak Ridge Reservation that are considered rare, threatened, or of special concern have been located, identified, and provided protection (Oak Ridge Operations 1975). At present nine candidate species are known to occur on the area. Efforts are being made to locate additional species that have been casually observed and reported but not verified by voucher specimens. The purpose of this activity is to sumarize present knowledge of the occurrence and distribution of threatened and endangered plant species for long-range management decisions of the DOF-Oak Ridge Reservation. 
THIS PAGE

WAS INTENTIONALLY

LEFT BLANK 
ABSTRACT ............................ $i$...

LIST OF TABLES ......................... ix

LIST OF FIGURES . . . . . . . . . . . . . . . . xi

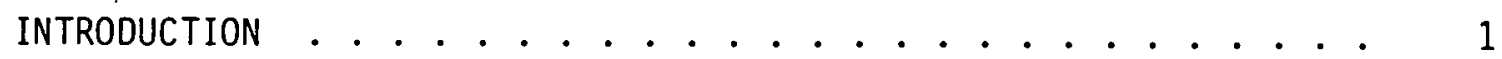

HABITAT AND SPECIES PRESERVATION ...................... 2

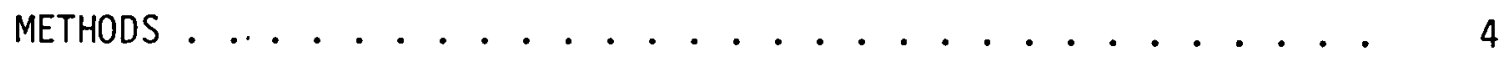

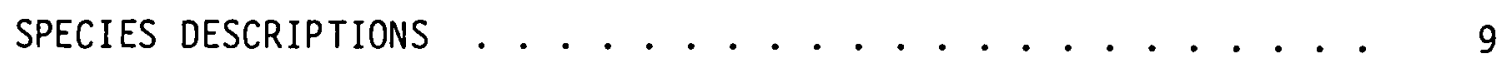

Bugbane (Cimicifuga rubifolia) . . . . . . . . . . 9

Ta11 Larkspur (Delphinium exaltatum) . . . . . . . . . . 11

Large Fothergilla (Fothergilla major) . . . . . . . . 13

Goldenseal (Hydrastis canadensis) . . . . . . . . . 15

Canada Lily (LiTium canadense) . . . . . . . . . . . 17

Ginseng (Panax quinquefolius) ........... 19

Sharp's Mock Orange (Philadelphus sharpianus) . . . . . . 21

Carey's Saxifrage (Saxifraga careyana) . . . . . . . 23

Lesser Ladies' Tresses (Spiranthes ovalis) . . . . . . . 25

REFERENCES .............................. 27 
THIS PAGE

WAS INTENTIONALLY

LEFT BLANK 


\section{LIST OF TABLES}

$\underline{\text { Table }}$

$1 \quad$ Plants of the Oak Ridge Reservation that are rare, threatened, or of special concern ........

2 Rare, threatened, or endangered plant species likely 
THIS PAGE

WAS INTENTIONALLY

LEFT BLANK 


\section{LIST OF FIGURES}

Figure

Page

County Occurrence Maps

1 Bugbane (Cimicifuga rubifolia) . . . . . . . . 10

2 Tal1 Larkspur (Delphinium exaltatum) . . . . . . . 12

3 Large Fothergilla (Fothergilla major) . . . . . . . 14

4 Goldenseal (Hydrastis canadensis) . . . . . . . . 16

5 Canada Lily (Lilium canadense) . . . . . . . . . 18

6 Ginseng (Panax quinquefolius) . . . . . . . . 20

7 Sharp's Mock Orange (Philadelphus sharpianus) . . . . 22

8 Carey's saxifrage (Saxifraga careyana) . . . . . . 24

9 Lesser Ladies' Tresses (Spiranthes ovalis) . . . . . 26 
INTRODUCTION

In 1973 the Endangered Species Act (U.S. Congress 1973) was expanded to include plants in addition to fish and wildlife already protected. As stated, "the purposes of this act are to provide a means whereby ecosystems upon which endangered species and threatened species depend may be conserved, to provide a program for the conservation of such endangered species and threatened species, and to take such steps as may be appropriate to achieve the purposes of the treaties and conventions set forth ..."

Sharp (1974) of the University of Tennessee published a list of "Rare Plants of Tennessee" in July 1974. He stated that "the only satisfactory way of avoiding the extinction of rare plants is the selection and maintenance of areas in which are found the peculiar habitats necessary to the ir survival." Life history studies and propagation may be alternative methods of not only avoiding plant extinction but also for obtaining knowledge necessary for selection and maintenance of the habitats of the plants.

The "Report on endangered and threatened plant species of the United States" was presented to Congress by the Secretary of the Smithsonian Institution in December 1974 (1'.S. Congress 1975). It included the first national tabulation of candidate species for designation as endangered, threatened, recently extinct, or commercially exploited plant species of the United States (including Alaska and Hawaii). Recommendations to Congress were presented, along with discussion of the value of retaining diverse plant species, causes of rarity, 
and preservation. The major recommendation made concerned the preservation of the habitats of endangered and threatened species of plants.

In May 1975 the U.S. Department of Agriculture, Soil Conservation Service, published "Rare, threatened, or endangered plant species of Tennessee." The report (Soil Conservation Service 1975) emphasized the importance of plant habitat consideration in land-use planning.

The U.S. Department of the Interior, Fish and Wildlife Service, printed the Smithsonian Report in 1975 (Federal Register 1975). The Director, U.S. Fish and Wildlife Service, has proposed that the approximately 1700 native, U.S. vascular plant taxa on the Smithsonian list be considered as endangered species.

A workshop on rare Tennessee plants was held November 18, 1976, to discuss and incorporate comments on a preliminary list of Tennessee rare plants prepared by members of the Tennessee Committee for Rare Plants (Tennessee Committee for Rare Plants, in press). In addition to discussing the list, concern was expressed regarding the need for accurate information regarding the status of Tennessee's rare plants in order to achieve environmentally sound land-use planning and development in the future.

Habitat and Species Preservations

The establishment of several natural areas on the Oak Ridge Reservation reflects the DOE concern for the preservation of unique or representative biotic features. In response to a request by the DOE Division of Biomedical and Environmental Research personnel, the Environmental Sciences Division at Oak Ridge National Laboratory reviewed the Fish and 
Wildlife Service Endangered Species list with regard to the DOE Oak Ridge Reservation. Most of the rare plants on the DOE Oak Ridge Reservation that have been located are in Environmental Research Park natural areas (Kitchings and Mann 1976). In order to ensure protection of additional species, efforts are being made to locate species that have been seen at one time but not verified by voucher specimens or species whose habitat requirements suggest there is a high probability they occur on the DOE Oak Ridge Reservation.

Locating and identifying endangered species are important first steps to be taken in species preservation. Long-term protection of sensitive species is potentially hampered by the lack of knowledge concerning species biology. Protection of endangered species in their native habitat is considered by some as the best method of ensuring their survival (Forest Service 1977). Indiscriminant modification or destruction of habitat could not only cause a reduction of the popula-. tion but could also result in a restriction of the population's expansion and recovery. Many species, however, are rare because they occupy unusual, of ten temporary habitats and may be dependent on some type of interference. Natural history studies and propagation of sensitive species are important in determining the plants' environmental requirements. Carefur management of the habitat might be necessary to maintain the species, but before any habitat can be managed to protect a species, it is necessary to determine whether the species is reproducing and its reproductive potential. Once propagules are dispersed it is essential to know the processes active in establishing the species. Thus, the 
species autecology must be studied to plan for scientific and beneficial management of the habitats where the species survive.

\section{Methods}

A combined rare plant list was compiled incorporating all candidate species included on each of the following lists: Soil Conservation Service (1975), Federal Register (1975), Tennessee Committee for Rare Plants (in press), and Sharp (1974). The computer output was an alphabetical listing of the species, the lists on which they occurred, and their current status.

The "combined rare plant list" was then compared to the species listed in "Oak Ridge, Tennessee, flora: Habitats of the vascular plants - Revised inventory" (Mann and Bierner 1975). Species included in the Mann-Bierner report are recorded from Anderson, Knox, Loudon, Morgan, and Roane Counties. Species listed as occurring in Anderson and Roane Counties were checked in the Oak Ridge National Laboratory (ORNL) and University of Tennessee (UT) herbaria to verify their identity and occurrence on the Oak Ridge Reservation.

A surmary of the status of rare plants on the DOE Oak Ridge Reservation is presented in Table 1. The three categories (rare, threatened, and special concern) are defined as follows:

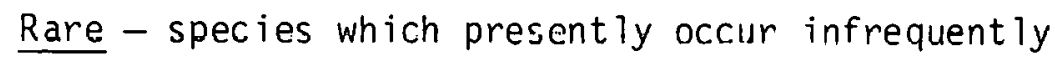
and are few and widely separated (possibly due to habitat destruction or commercial exploitation). Threatened - as described by Tennessee Committee for Rare Plants (1978), species likely to become 
Table 1. Plants of the Oak Ridge. Reservation that are rare, threatened or of special concern

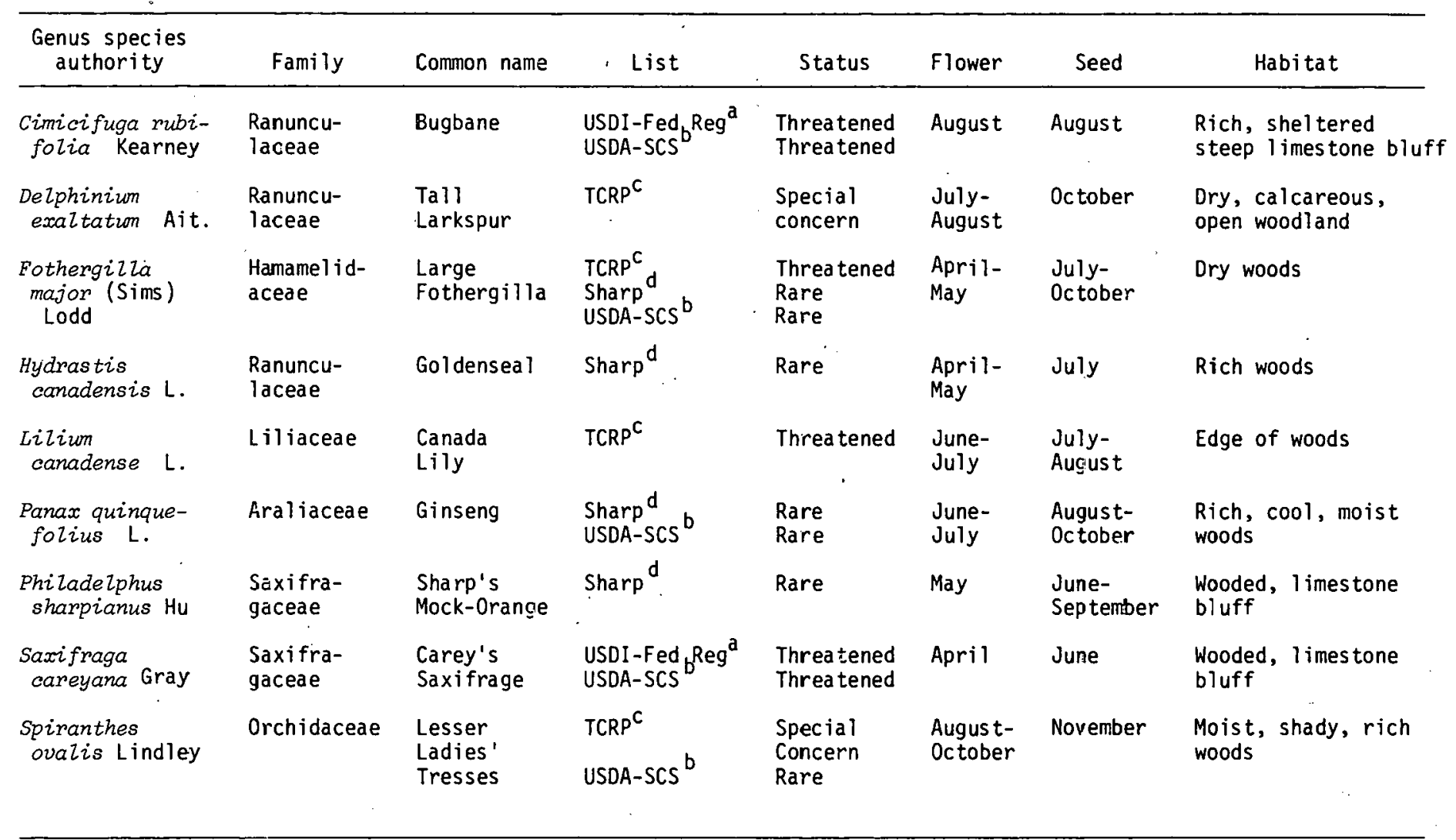

${ }^{a}$ Federal Register. Threatened or Endangered Fauna or Flora, Vol. 40, No. 127, 1975.

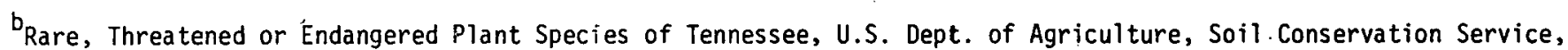
Nashville, May 1975 .

C Tennessee Committee for Rare Plants, J. L. Collins (TVA), H. R. DeSelm (UT), A. M. Evans (UT), R. Kral (Vanderbilt) and B. E. Wofford (UT), September 1976.

${ }^{d}$ Sharp, A. J. Tennessee Conservationist, July 1974. 
endangered in the immediately foreseeable future as

a result of present rapid habitat destruction or commercial exploitation.

Special Concern - plants listed by Tennessee

Committee for Rare Plants (1978) as requiring

particular attention because they are at the limit

or near-limit of the geographic range in Tennessee,

or because their status is undetermined due to

insufficient information.

Information concerning common name, phenology, habitat, and basis for sketches was obtained from both reference materials and herbarium specimens. Actual habitat where each species was found was, of course, determined from the herbarium label or collector. A county occurrence map (obtained from U.T. herbarium collections) is provided for each species, annotated to incorporate ORNL records. Each species is provided with a brief description of identifying characters, habitat where collected, and the name of the investigator.

A list of some rare, threatened, or endangered plant species likely to occur on the Oak Ridge Reservation is presented in Table 2 . Most plants included on this sumary are those that have been found and ver $i-$ fied in neighboring counties and have habitat requirements that may possibly be found on the Oak Ridge Reservation. Other plants on the list are those which have been seen, but not verified.

Three plant species, although not listed on any rare plant species lists for Tennessee, are of special interest in this area. Trailing arbutus (Epigea repens L.) has become scarce or has disappeared over a 
Table 2. Rare, threatened or endangered plant species likely to occur on the Oak Ridge Reservation

\begin{tabular}{|c|c|c|c|c|c|c|}
\hline $\begin{array}{l}\text { Genus species } \\
\text { authority }\end{array}$ & Family & Common name & List & Status & Flower & Habitat \\
\hline $\begin{array}{l}\text { Asplenium bradleyi } \\
\text { D. C. Eaton }\end{array}$ & Polypodiaceae & $\begin{array}{l}\text { Bradley's } \\
\text { Spleenwort }\end{array}$ & Sharp ${ }^{a}$ & Rare & $\begin{array}{l}\text { June- } \\
\text { September }\end{array}$ & $\begin{array}{l}\text { Crevices of acidic } \\
\text { rocks and cliffs }\end{array}$ \\
\hline $\begin{array}{l}\text { Aureolaria patula } \\
\text { (chapm.) Pennell }\end{array}$ & Scrophulariace & $\begin{array}{l}\text { False } \\
\text { Foxglove }\end{array}$ & $\begin{array}{l}\text { USDI -Fed }{ }_{\text {Reg }}^{b} \\
\text { USDA-SCS }\end{array}$ & Threatened. & - & Woods \\
\hline $\begin{array}{l}\text { Disporwm maculatwm } \\
\text { (Brickley) Britton }\end{array}$ & Liliaceae & $\begin{array}{l}\text { Nodding } \\
\text { Mandarin }\end{array}$ & Sharp ${ }^{a}$ & Rare & May & Rich woods \\
\hline $\begin{array}{l}\text { Echinacea purpurea } \\
\text { (L.) Moench }\end{array}$ & Compositae & $\begin{array}{l}\text { Purple Cone- } \\
\text { flower }\end{array}$ & Sharp ${ }^{a}$ & Rare & $\begin{array}{l}\text { June- } \\
\text { October }\end{array}$ & $\begin{array}{l}\text { Woodlands, prairies } \\
\text { and road banks }\end{array}$ \\
\hline $\begin{array}{l}\text { Lizium grayii } \\
\text { Watson }\end{array}$ & Liliace & Gray's Lily & USDI-Fed Reg ${ }^{b}$ & Threa tened & $\begin{array}{l}\text { June- } \\
\text { July }\end{array}$ & $\begin{array}{l}\text { Rich, moist woods } \\
\text { in mountains }\end{array}$ \\
\hline $\begin{array}{l}\text { Orontium } \\
\text { aquaticum L. }\end{array}$ & Araceae & Golden Club & Sharp ${ }^{a}$ & Rare & $\begin{array}{l}\text { March- } \\
\text { April }\end{array}$ & $\begin{array}{l}\text { Swamps and shallow } \\
\text { acidic streams }\end{array}$ \\
\hline $\begin{array}{l}\text { Petalostemum } \\
\text { folioswm Gray }\end{array}$ & Fabaceae & Prairie Clover & $\begin{array}{l}\text { USDI -Fed }{ }_{\text {Reg }}{ }^{b} \\
\text { USDA-SCS }\end{array}$ & Endangered & $\begin{array}{l}\text { July- } \\
\text { September }\end{array}$ & River banks \\
\hline $\begin{array}{l}\text { Silene rotundi- } \\
\text { folia Nutt. }\end{array}$ & Caryophyllaceae & $\begin{array}{l}\text { Round-leaved } \\
\text { Catchfly }\end{array}$ & Sharp ${ }^{a}$ & Rare & June-July & $\begin{array}{l}\text { Exposed cliffs } \\
\text { and banks }\end{array}$ \\
\hline $\begin{array}{l}\text { Ulmus crassi- } \\
\text { folia Nutt. }\end{array}$ & Ulmaceae & Cedar Elm & Sharp ${ }^{a}$ & Rare & - & - \\
\hline
\end{tabular}

a Sharp - Tennessee Conservationist, July 1974.

bederal Register - Threatened or Endangered Fauna or Flora, Vol. 40, No. 127, 1975.

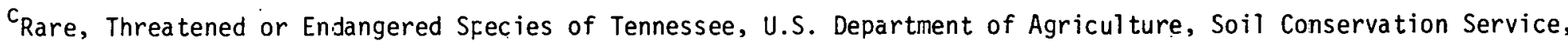
Nashville, May 1975. 
large part of its extensive range. In remote areas and in places where it is protected, it continues to thrive (Stupka 1965). This prostrate shrub occurs frequently on the DOE-Oak Ridge Reservation growing on gravelly, wooded, acidic slopes. Prickly pear [0puntia compressa (Salisb.) Macbr.] is abundant in the cedar glades and limestone soil of Marshall and Rutherford Counties, Tennessee. Occurrence on the DOE-Oak Ridge Reservation is 1 imited to cedar barrens of 1 imestone outcroppings. Scarcity of prickly pear in this area is most likely due to absence of appropriate habitat substrata. Compass plant (Silphium terebrinthinaceum Jacq.) is indicative of prairie. Its presence on the DOE-0ak Ridge Reservation may actually be increasing due to opening up and clearing of previously forested areas.

With increased demands on natural resources, land management decisions and practices have an added potential to influence the status of threatened and endangered plant species. The review of the status of plant species in any area is a logical first step in summarizing the present knowledge of the occurrence and distribution of rare or endangered species. A primary purpose of this activity has been to verify the identity and existence of endangered species on the Oak Ridge Reservation. A secondary objective has been to stimulate interest in species biology. Knowledge of species biology, combined with occurrence and distribution data, is essential to delineate maintenance strategies for 1 and management decisions. 
Bugbane

Cimicifuga rubifolia Kearney

Buttercup family (Ranunculaceae)

A perennial herb with 5 to 9 prominent veins arising at the base of a deeply cordate terminal leaflet. Flowers in elongate virgate racemes. Seeds scaly and cylindrical (Ramsey 1965).

Habitat of rich, sheltered, steep, limestone bluff. Flowers and fruit in August.

Occurrence reported in 13 counties including Anderson and Roane (Fig. 1).

Listed in the U.S. Department of Interior-Federal Register as threatened and by the U.S. Department of Agriculture-So il Conservation Service, Nashville, as threatened.

Collected by $\mathrm{J}$. Wolfe and $G$. Ramsey in April 1963 and by L. K. Mann and P. D. Parr in July 1976.

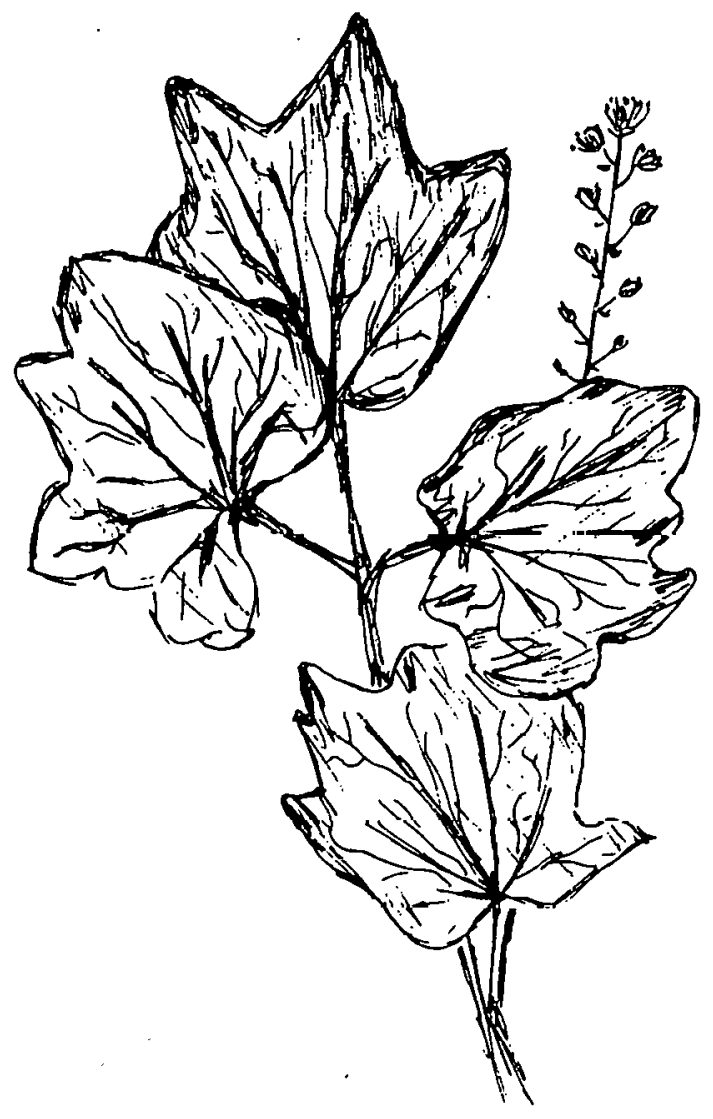

Cimicifuga rubifolia 


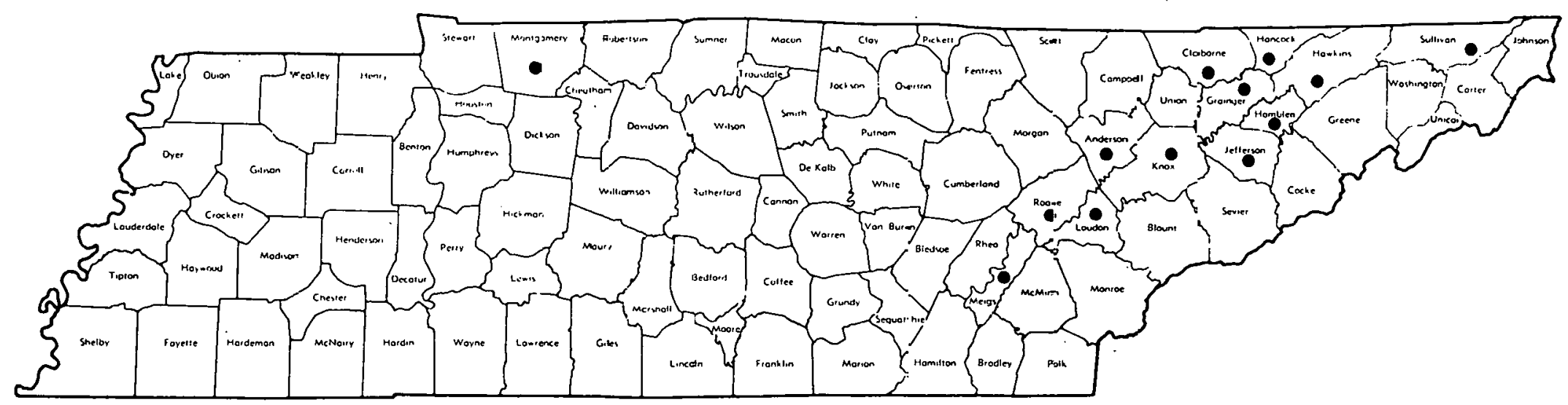

Figure 1

MAP OF TENNESSEE BY COUNTIES

Cimicifuga rubifolia Kearney

Dots (•) indicate occurrence only and not region of the county where collected. 
Ta 11 Larkspur

Delphinium exaltatum Ait.

Buttercup family (Ranunculaceae)

A perennial herb with smooth, erect stems up to $2 \mathrm{~m}$ tall. Large leaves, pale beneath, are divided into a few cuneate to lanceolate segments, these with 1 to 4 coarse, sharp lobes above the middle. Often branched, elongate raceme with spurred blue flowers. Seeds 3-angled, wrinkled, and shining (Gleason and Cronquist 1967).

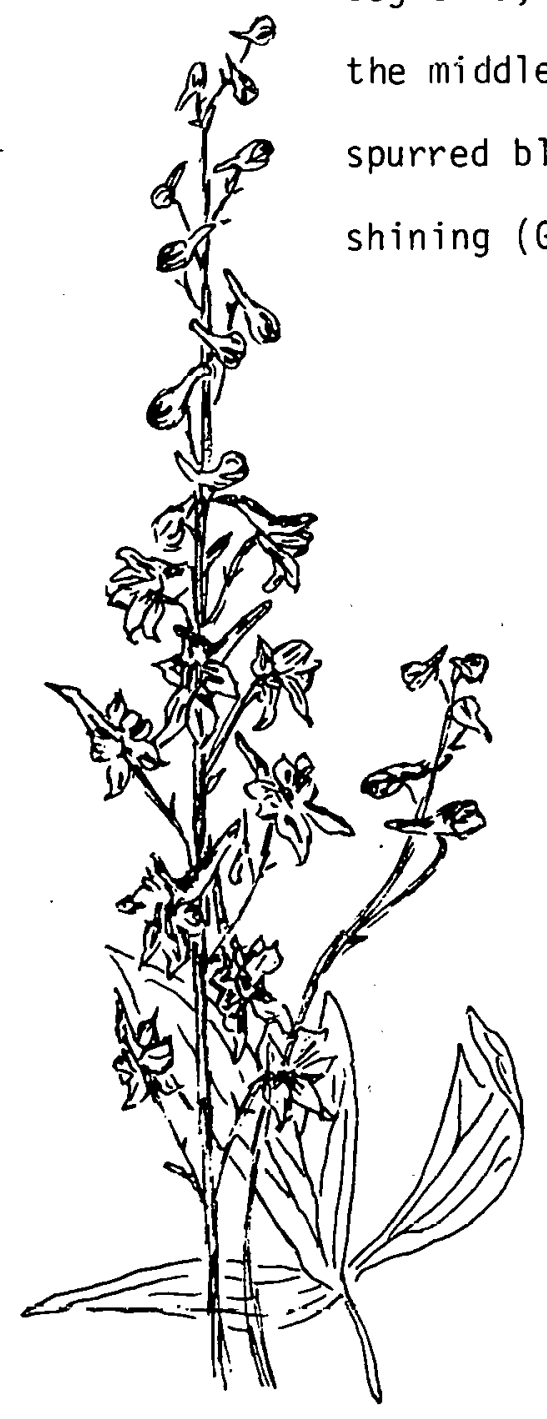

Habitat of dry, calcareous, open woods. Flowers mid-July to mid-August with fruit in October. Occurrence reported in Anderson county only (Fig. 2).

Listed by the Tennessee Committee for Rare Plants as a species of special concern due to danger of becoming extinct because of rarity throughout their range and as a result of sensitive habitat or. restricled area of distribution.

Collected by W. H. Ellis in August 1961 Delphinium exaltatum and by L. K. Mann in July 1976. 


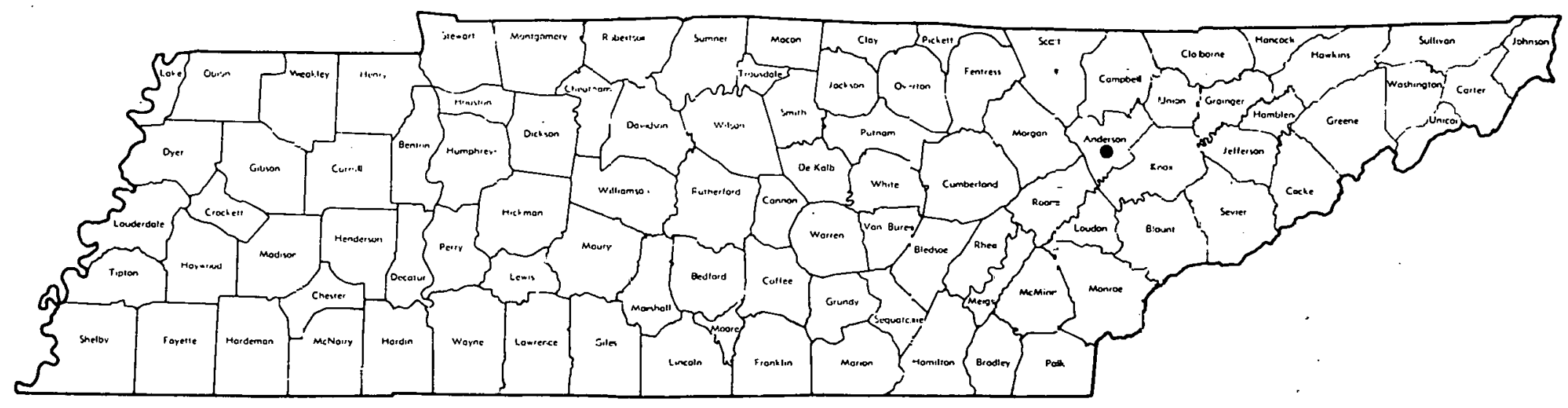

\section{Figure 2}

MAP OF TENNESSEE BY COUNTIES

Delphinium exaltatum Ait.

Dots (0) indicaice occurrence only and not region of the county where collected. 
Large Fothergilla

Fothergilla major (Sims) Lodd

Witch-hazel family (Hamamelidaceae)

A medium-sized shrub 0.5 to $1.5 \mathrm{~m}$ tall with stiff, upright branches. Leaves 2 to 4 in. long, sometimes to 6 in., suborbicular, broad-elliptic or obovate. Flowers in clusters to 2 in. long (Viertel 1970).

Habitat of west-facing, open, wooded slope. Flowers April-May with fruit July-October. Occurrence is reported in 5 counties including Anderson (Fig. 3).

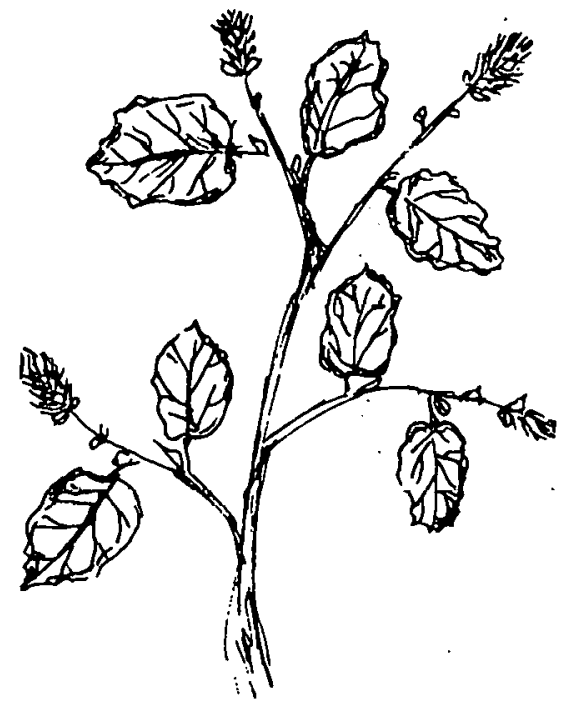

Fothergille major
Listed by the Tennessee Committee for Rare Plants as a threatened species likely to become endangered in the immediately foreseeable future.

Observed and recorded by L. K. Mann in April 1975. 


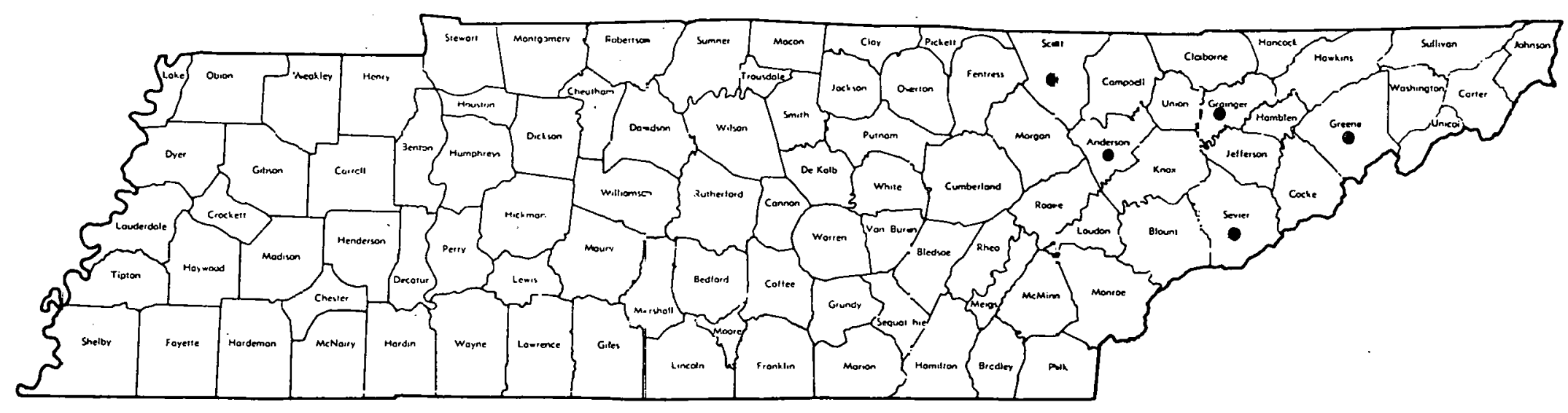

Figure 3

MAP OF TENNESSEE BY COUNTIES

Fothergizla major (Sims) Lodd

Dots (0) indicate occurrence only and not region of the county where collected. 
Goldensea ?

Hydrast is canadens is $L$.

Buttercup family (Ranunculaceae)

A perennial herb 2 to $5 \mathrm{dm}$ high bearing one basal leaf and two cauline leaves near the summit. Leaves rounded, cordate at the base, 5 to 7 lobed, doubly serrate and veiny. Flower about $15 \mathrm{~mm}$ wide. Fruit is a head of dark, red berries (Gleason 1952).

Habitat of narrow drainage, steep, north facing slope of old growth in rich woods, also open cedar-oak woods on a limestone outcropping. Flowers April-May with fruit in July. Occur-

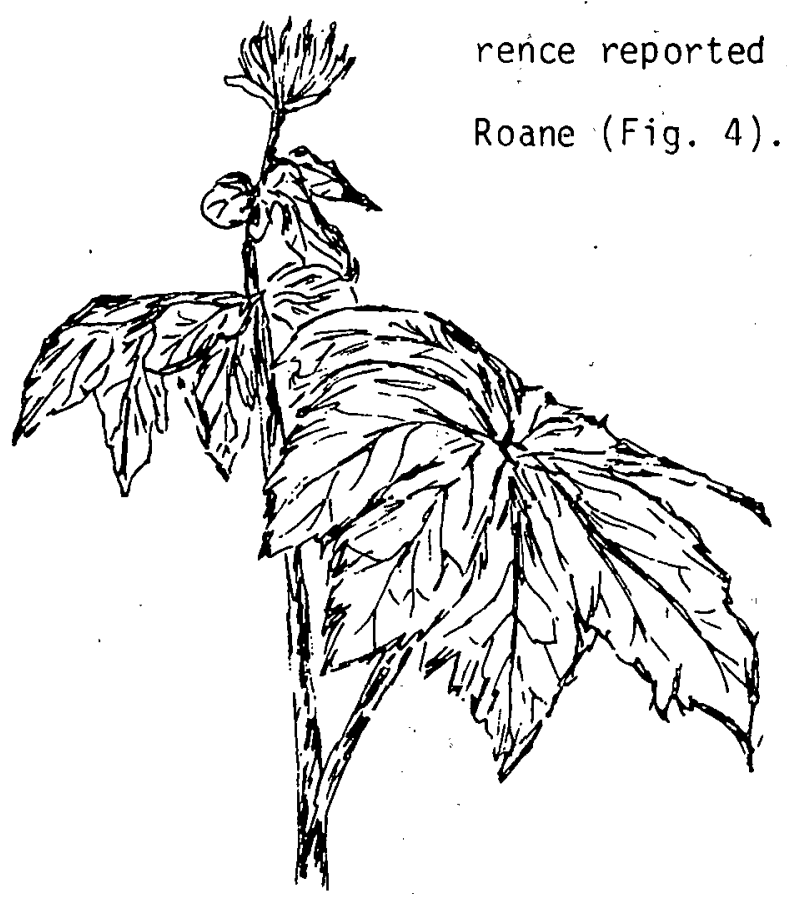

This plant has been largely eliminated because it is much sought for medicine. A. J. Sharp lists this species as rare.

Observed and recorded by L. K. Mann in 1976 and by J. T. Kitchings 1976 .

Hydrastis canadensis 


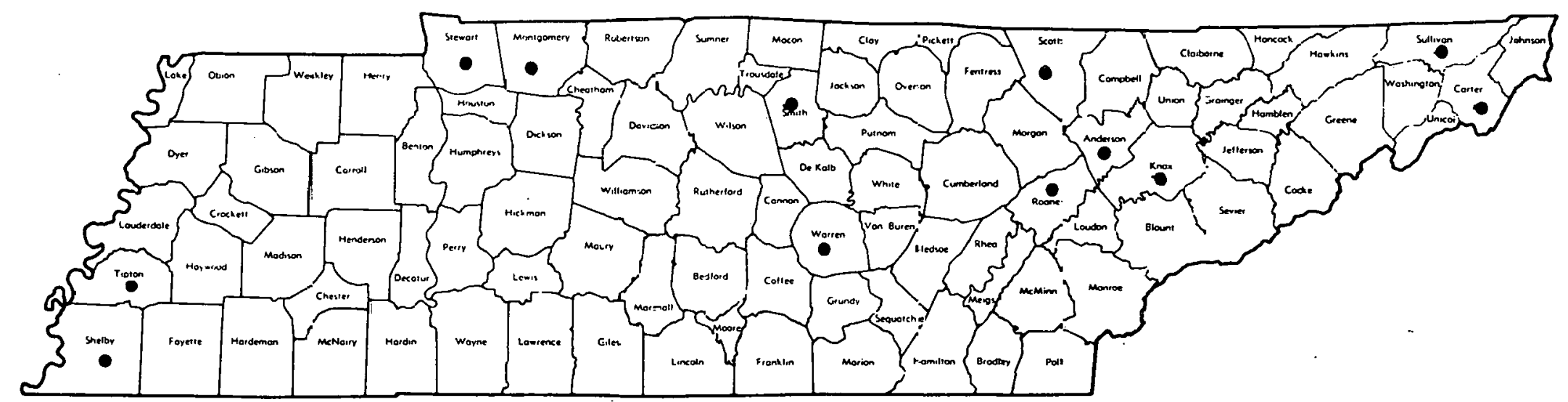

Figure 4

MAP OF" TENNESSEE BY COUNTIES

Hy.drastis canadensis $\mathrm{L}$.

Dots (0) indicate occurrence only and not region of the county where collected. 
Canạda Li ly

Lilium canadense $L$.

Lily family (Liliaceae)

Perennial with slender stem, erect, 6 to $15 \mathrm{dm}$ tall. Leaves mostly in whorls of 4 to 12. Flowers yellow or orange-yellow to red marked with purple spots within (Gleason and Cronquist 1967).

Roadside or edge of woods type of habitat. Flowers in June-July with fruit July-August. Occurrence reported in 9 counties including Roane (Fig. 5).

Listed as threatened by the Tennessee Committee for Rare Plants and considered likely to become endangered in the immediately foreseeable future.

Collected July 1966 by N. C. Griffin and observed and recorded by L. K. Mann the summer of 1976.

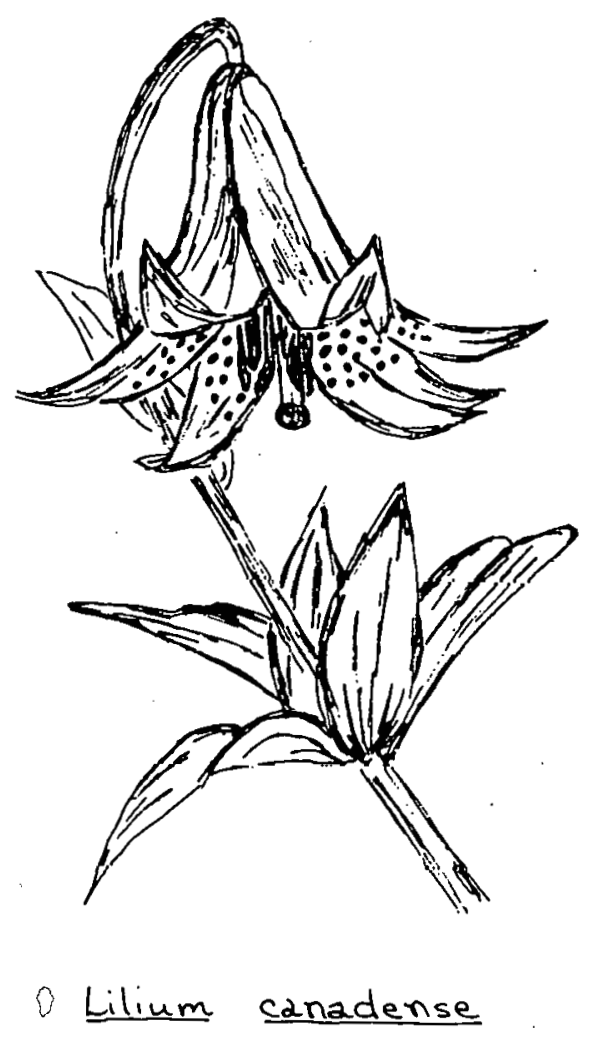




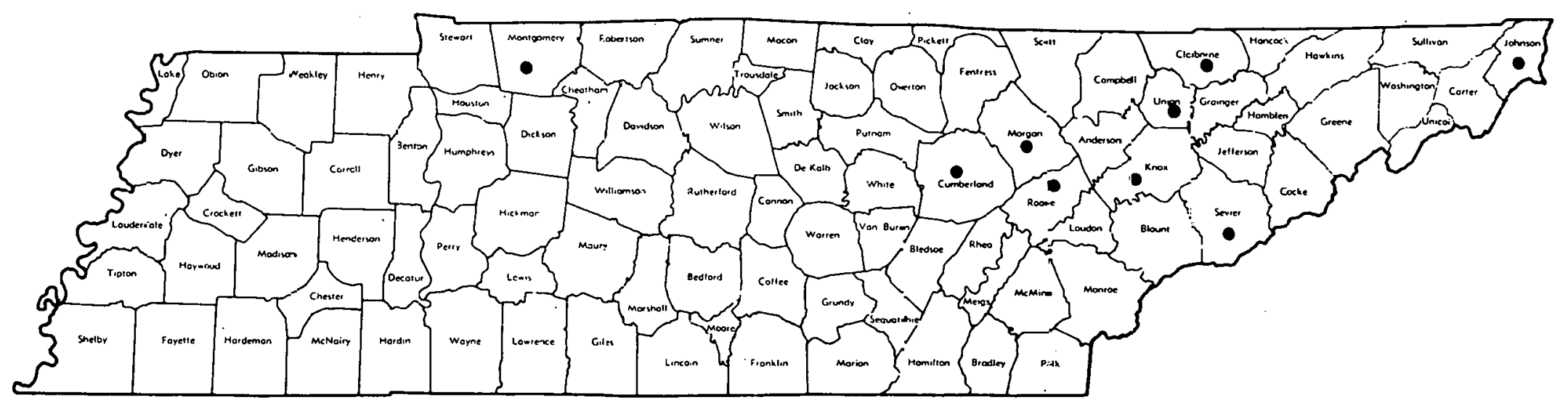

Figure 5

MAP OF TENNESSEE BY CQUNTIES Lizium canadense $L$.

Dots ( $)$ indicate occurrence only and not region of the county where collected. 
Ginseng

Panax quinquefolius L.

Ginseng family (Araliaceae)

A perennial herb 2 to $6 \mathrm{dm}$ tall. Leaves 3 to 4 with 3 to 5 leaflets, elliptic or obovate, acuminate, serrate, and petiolulate (Radford et al. 1968). Flowers reddish-white. Bright red fruit.

Habitat of rich, cool, shaded, moist woods. Flowers June-Juily with fruit August-0ctober. Recorded occurrence in 17 counties including Anderson and Roane (Fig. 6).

Much sought for the root used in medicine and is now in danger due to this exploitation. Listed by $A$.

J. Sharp as rare and by the U.S. Department of Agriculture-Soil Conservation Service, Nashville as rare.

Collected by S. Cristofolini

and G. Cristofolini July 1965.

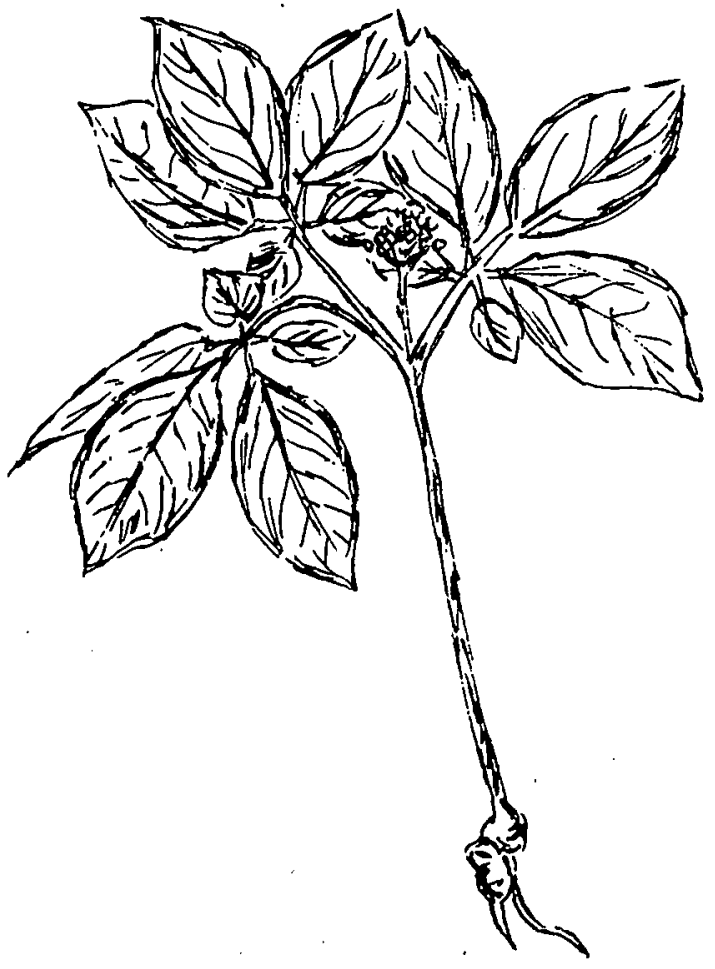

Panax quinquefolius 


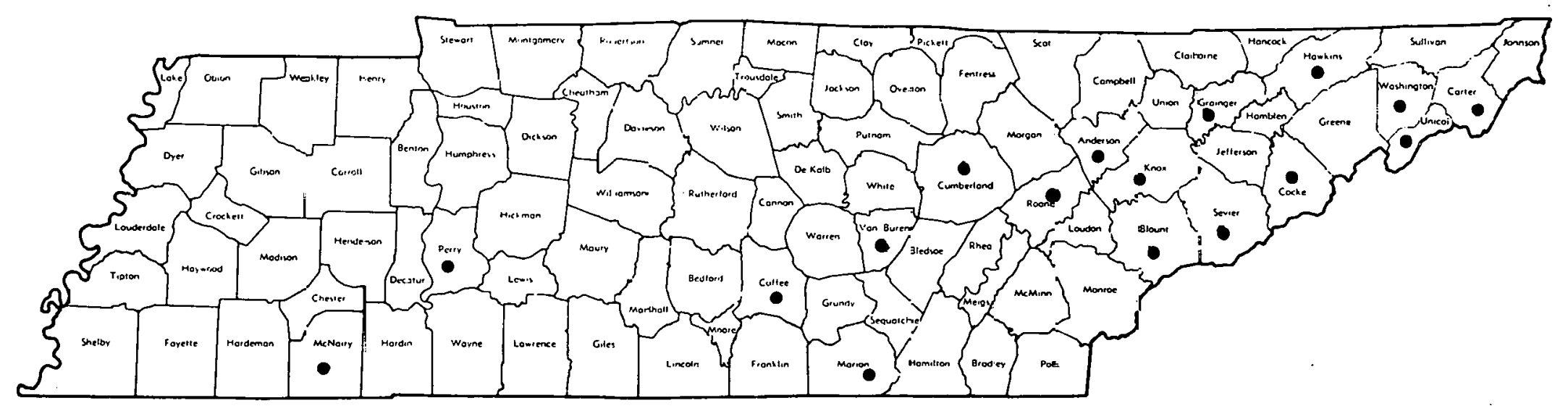

Figure 6

MAP OF TENNESSEE BY COJNTIES

Ponax quinquefolius $\mathrm{L}$.

Dots (•) indicate occurrence only and not region of the county where collected. 
Sharp's Mock Orange

Philadelphus sharpianus Hu

Saxifrage family (Saxifragaceae)

A shrub with simple, opposite, toothed leaves. Flowers usually with 4 rounded-obovate petals, solitary or in terminal cymes.

Habitat of a wooded limestone bluff facing the river and exposed limestone bluff at the surface of the water. Flowers in May with fruit June-September. Recorded occurrence in 10 counties including Anderson

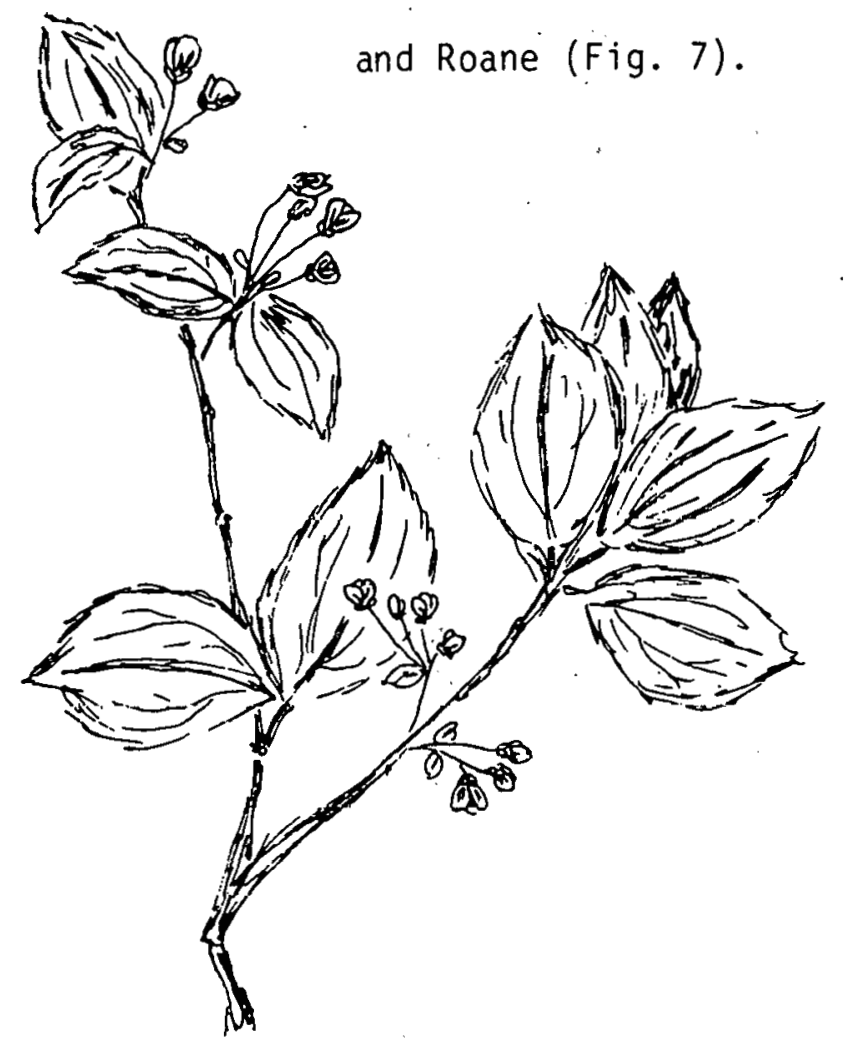

Listed by Sharp (1974) as rare.

Collected by W. H. Ellis in August 1961 and by F. G. Taylor and P. D. Parr in September 1976.

Philadelphus sharpianus 


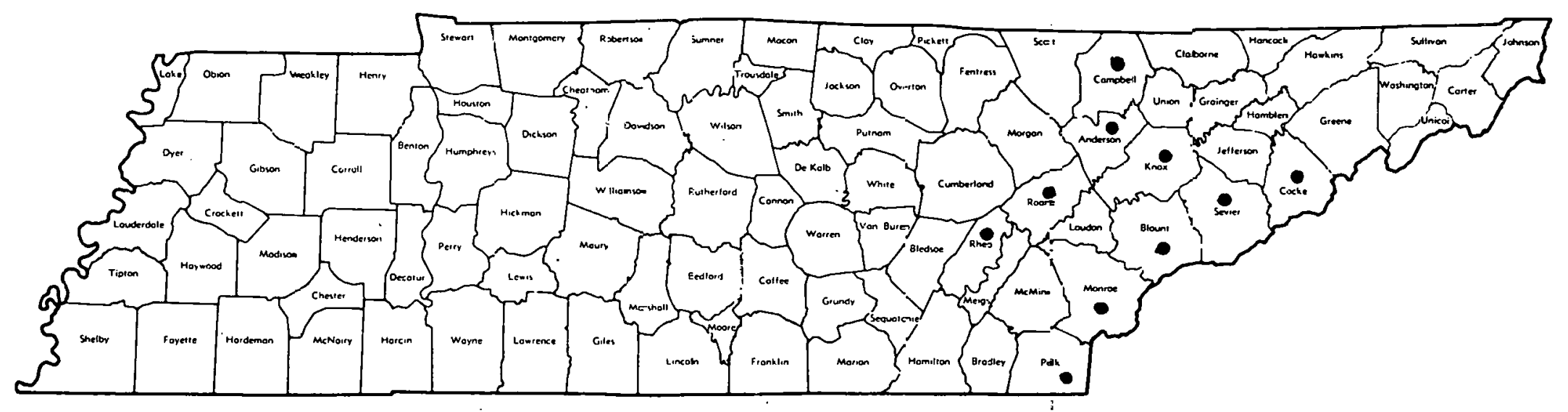

\section{Figure 7}

MAP OF TENNESSEE BY COUNTIES

Phi:adelphus sharpianus Hu

Dots (0) indicate occurrence only and not region of the county where collected. 
Carey's Saxifrage

Saxifrage careyana Gray

Saxifrage family (Saxifragaceae)

A perennial herb 1 to $5 \mathrm{dm}$ tall. Basal leaves which are ovate to slightly obovate. Calyx tube campanulate. Capsules usually 2.5 to $3 \mathrm{~mm}$ long (Radford et al. 1968).

Habitat of wooded limestone bluff facing the river and dolomite bluffs above the river. Flowers April-May with fruit in June. Recorded occurrence in 18 counties including Anderson and Roane (Fig. 8).

Listed as threatened in the U.S. Department of the Interior-Federal Register and also by the U.S. Department of Agriculture-Soil Conservation Service, Nashville.

Collected by W. H. Ellis June

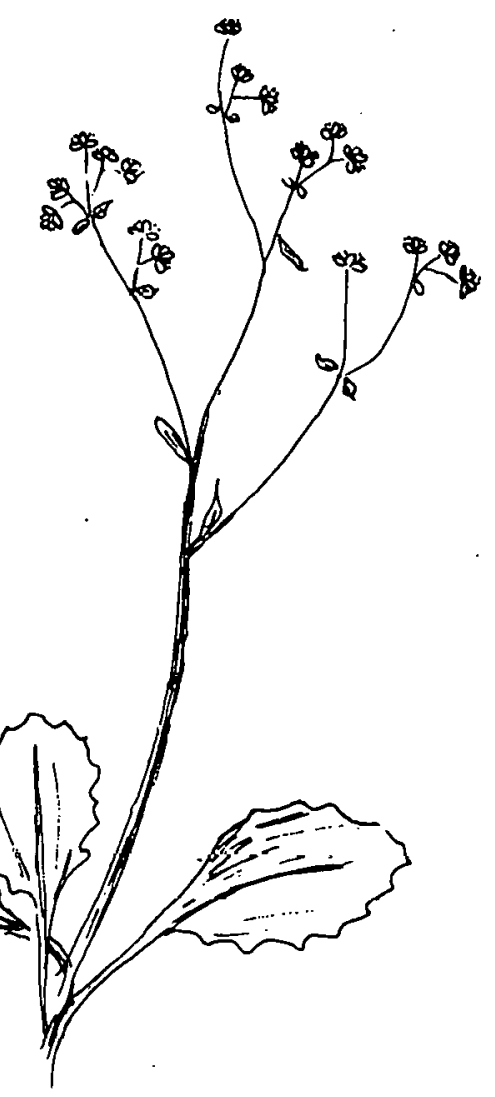
1961 and by B. Hale and E. E. C. Clebsch April 1974. Saxiftaga careyana 


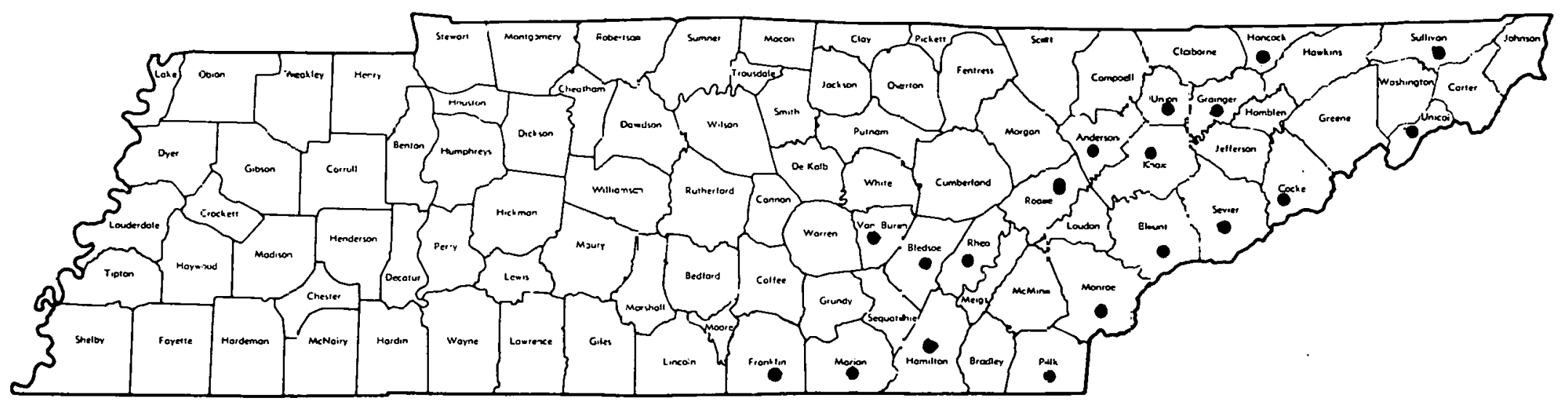

Figure 8

MAP OF TENNESSEE BY CCUNTIES

Scxifraga careyana Gray

Dots (o) indicate occurrence only and not region of the county where collected. 
Lesser Ladies' Tresses

Spiranthes ovalis Lind ley

Orchid family (Orchidaceae)

A perennial herb 1.5 to $4 \mathrm{dm}$ high. Leaves basal and cauline, deep green, oblanceolate, tapering to a long, petiolar base. Slender spike of several ranks of small, white flowers, 4 to $5 \mathrm{~mm}$ long, subacute to acute with an ovate lip (Fernald 1950).

Habitat of moist, rich, shady woods. Flowers August-0ctober with fruit in November. Recorded

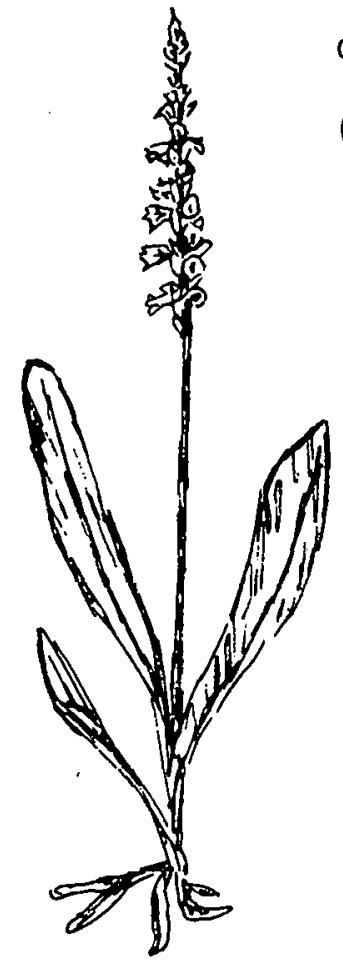

Spiranthes ovalis occurrence in 3 counties including Roane and Anderson (Fig. 9).

Listed as a species of special concern by the Tennessee Committee for Rare Plants because they are rare in Tennessee because the state represents the limit or near limit of the ir geographic range. The U.S. Department of Agriculture-Soil Conservation Service, Nashville, considers their status as rare.

Collected by F. G. Taylor October 1966 and by J. M. Klopatek and N. T. Edwards in October 1976. 


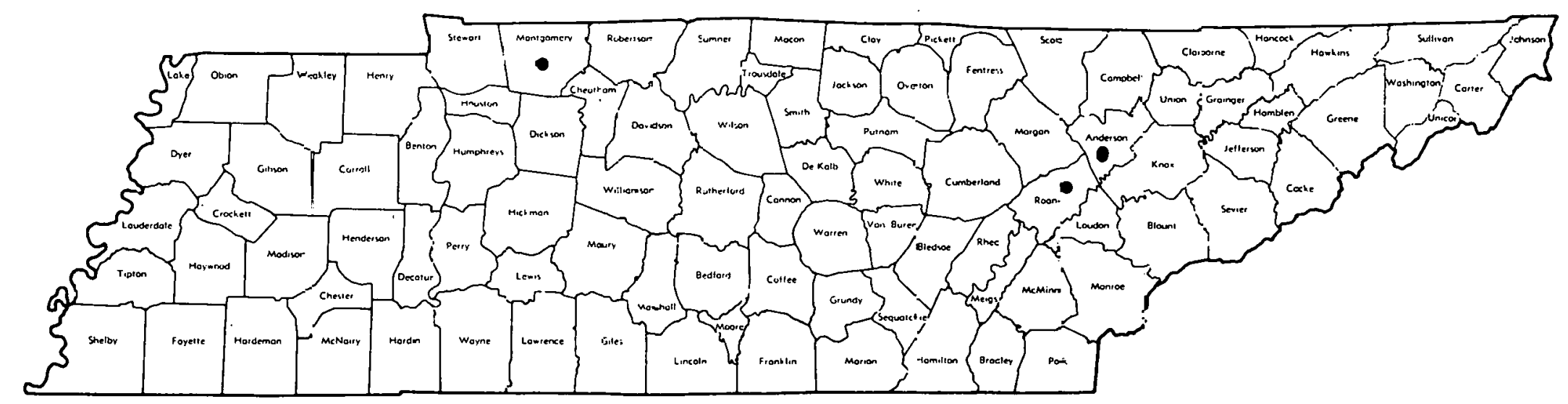

Figure 9

MAP OF TENNESSEE BY COUNTIES

Spiranthes ovalis Lindley

Dots (ט) indicate occurrence only and not region of the county where collected. 


\section{REFERENCES}

Federal Register. 1975. Threatened or endangered fauna or flora. U.S. Department of the Interior. Fed. Regist. 40(127).

Fernald, M. L. 1950. Gray's Manual of Botany. Eighth Edition. American Book Company, New York. 1632 pp.

Forest Service. 1977. Conference on endangered plants in the southeast, proceedings. U.S. Department of Agriculture, Forest Service General Technical Report SE-11.

Gleason, H. A. 1952. The New Britton and Brown Illustrated Flora of the Northeastern United States and Adjacent Canada. 3 volumes. New York Botanical Garden, New York.

Gleason, H. A., and A. Cronquist. 1967. Manual of Vascular Plants of Northeastern United States and Canada. D. Van Nostrand Company, Inc., Princeton, New Jersey. 809 pp.

Kitchings, J. T., and L. K. Mann. 1976. A description of the terrestrial ecology of the Oak Ridge Environmental Research Park. ORNL/TM-5073. Oak Ridge National Laboratory, Oak Ridge, Tennessee. Mann, L. K., and M. W. Bierner. 1975. Oak Ridge, Tennessee, flora:

Habitats of the vascular plants - revised inventory. ORNL/TM-5056. Oak Ridge National Laboratory, Oak Ridge, Tennessee. Oak Ridge Operations. 1975. Oak Ridge Reservation Land-Use Plan. ORO748. Technical Information Center, Oak Ridge, Tennessee.

Radford, A. E., H. E. Ahles, and C. R. Bell. 1968. Manual of the Vascular Flora of the Carolinas. University of North Carolina Press. Chapel Hill, North Carolina. 1183 pp. 
Ramsey, G. W. 1965. A biosystematic study of the genus Cimicifuga (Ranunculaceae). Dissertation presented to Graduate Council of the University of Tennessee, Knoxville, Tennessee.

Sharp, A. J. 1974. Rare plants of Tennessee. Tenn. Conserv. XL(7): $20-21$.

Shosteck, R. 1974. Flowers and Plants. New York Times Book Company. $329 \mathrm{pp}$.

Soil Conservation Service. 1975. Rare, threatened or endangered plant species of Tennessee. U.S. Department of Agriculture, Nashville, Tennessee.

Stupka, A. 1965. Wildflowers in Color. Harper and Row, New York.

Tennessee Committee for Rare Plants. The rare vascular plants of

Tennessee. J. Tenn. Acad. Sci. (in press).

U.S. Congress. 1973. Endangered Species Act of 1973. Report No. 94-A, 93rd Congress. U.S. Government Printing Office, Washington, D.C.

U.S. Congress. 1975. Report on endangered and threatened plant species of the United States. Report No. 94-A, 94th Congress, House Document No. 94-51. U.S. Government Printing Office, Washington, DC. $200 \mathrm{pp}$.

Vierte1, A. T. 1970. Trees, Shrubs and Vines. Syracuse University Press, Syracuse, New York. 
ORNL/TM-6101

INTERNAL DISTRIBUTION

1-20. S. I. Auerbach

21. D. M. Bradburn

22. R. W. Brocksen

23. R. L. Burgess

24. C. C. Coutant

25. R. B. Craig

26. N. T. Edwards

27. T. Grizzard

28. W. F. Harr is

29. R. J. Haynes

30. F. O. Hoffman

31. J. W. Huck abee

32. J. R. Hyndman

33. J. T. Kitchings

34. J. M. Klopatek

35. R. L. Kroodsma

36. L. K. Mann

37. R. K. McConathy

38. S. B. McLaughlin

39. K. M. Oakes

40. J. S. 01son
41. J. W. Pardue

42-51. P. D. Parr

43. Herman Postma

44. D. E. Reichle

45. C. R. Richmond

46. B. M. Ross

47. H. H. Shugart

48. A. M. Solomon

49. J. D. Story

50. E. G. Struxness

51. F. G. Taylor, Jr.

52. D. E. Todd, Jr.

53. D. C. West

54. J. P. Witherspoon

55. Biology Library

56-57. Central Research Library

58-59. Laboratory Records Dept.

60. Laboratory Records, ORNL-RC

61. ORNL Y-12 Technical Library

62. ORNL Patent Office

\section{EXTERNAL DISTRIBUTION}

63. Research and Technical Support Division, DOE-ORO

64. I. L. Brisbin, Savannah River Ecology Laboratory, Aiken, SB 29801

65. C. Cahoon, Department of Energy, Savannah River Operations Office, Savannah River Plant, Aiken, SC 29801

66. E. D. Campbe11, Nevada Operations Office, Department of Energy, Las Vegas, NV 89114

67. Carson Newman College, Library, Jefferson City, TN 37760

68. E. E. C. Clebsch, 408 10th Street, Graduate Program in Eco logy, University of Tennessee, Knoxville, TN 37916

69. R. Clements, Puerto Rico Nuclear Center, Mayaguiz, PR 00708

70. J. L. Collins, Tennessee Valley Authority, Forestry Building, Norr is, TN 37828

71. E. R. Cox, Department of Biology, Tennessee Wesleyan College, Athens, TN 37303

72. H. R. DeSe 1m, 408 10th S.treet, Graduate Program in Ecology, University of Tennessee, Knoxville, TN 37916

73. East Tennessee State University, Library, Johnson City, TN 37601

74. L. B. Edwards, Math and Science Department, Roane State Commun ity College, Rockwood, TN 37854 
75. A. M. Evans, Botany Department, University of Tennessee, Knoxville, TN 37916

76. R. E. Farmer, Jr., Tennessee Valley Authority, Forestry Building, Norr is, TN 37828

77. J. Franklin, Northwest Forest Research Laboratory, USFS, Corvallis, OR 97330

78. W. C. Hanson, Los Alamos Scientific Laboratory, Los Alamos, NM 87545

79. R. S. Harvey, E. I. DuPont de Nemours, Savannah River Laboratory, Aiken, SC 29801

80. J. Henderson, Biology Department, Oak Ridge High School, Oak Ridge, TN 37830

81. B. H. Hutchison, U.S. Department of Commerce, Atmospheric Turbulence and Diffusion Laboratory, Tulane Avenue, 0ak Ridge, TN 37830

82. L. J. Johnson, Los Alamos Scientific Laboratory, LoS Alamos, NM 87545

83. Ralph Jordan. T.V.A. Heritage Prngram Forestry Ruilding, Norr is, TN 37828

84. Knoxville College, Library, 901 College Street NW, Knoxville, TN 37916

85. R. Kral, Department of General Biology, Vanderbilt University, Nashvi118, TN 32703

86. Lincoln Memorial University, Library, Harrogate, TN 37752

87. J. L. Liverman, Division of Biomedical and Environmental Research, Department of Energy, Washington, OC 20545

88. B. Manowitz, Brookhaven National Laboratory, Brookhaven, L.I., NY 11973

89. 0. D. Markham, Idaho National Engineering Laboratory, Idaho Operations Office, Idaho Falls, ID 83401

90. Maryville College, Library, Maryville, TN 37801

91. Tim McCa11, Tennessee Field Office, 720 West End Avenue, Suite 600, Nashville, TN 37203

92. J. F. McCormick, OES, Fish and Wildlife Service, U.S. Department of Interior, Washington, D.C. 20240

93. Oak Ridge High School, Library, Oak Ridge, TN 37830

94. W. S. Osburn, Division of Biomedical and Environmental Research, Department of Energy, Washington, DC 20545

95. W. H. Rickard, Pac ific Northwest Laboratories, Richland, WA 99352

96. Roane State Commun ity College, Library, Rockwood, TN 37854

97. A. F. Robinson, Jr., U.S. Department of Agriculture, 1720 Peachtrec Rd., N. W., Atlanta, GA 30309

98. J. M. Safley, U.S. Department of Agriculture, So il Conservation Service, 561 U.S. Courthouse, Nashville, TN 37203

99. K. M. Schreiner, Associate Director-Federal Assistance, U.S. Fish and Wildiife Service, U.S. Department of Interior, Washington, D.C. 20240

100. A. J. Sharp, Department of Botany, University of Tennessee, Knoxville, TN 37916 
101. Smithsonian Institution, Endangered Flora Project, Department of Botany, Washington, D.C. 20560

102. D. Sprugel, Argonne National Laboratory, Argonne, IL 60439

103. Jeff Swinebroad, National Science Foundation, Washington, DC 20550

104. D. E. Slade, Division of Biomedical and Environmental Research, Department of Energy, Washington, DC 20545

105. Tennessee Technological University, Library, Cookeville, TN 38501

106. University of Tennessee, Library, Chattanooga, TN 37405

107. Robert Watters, Division of Biomedical and Environmental Research, Department of Energy, Washington, D.C. 20545

108. W. K. Willard, Biology Department, Tennessee Technological University, Cookeville, TN 38501

109. B. E. Wofford, Department of Botany, University of Tennessee, Knoxville, TN 37916

110. D. W. Yambert, Tennessee Wildlife Resources Agency, Ellington Agricultural Center, P.0. Box 40747, Nashville, TN 37204

111-137. Technical Information Center, Oak Ridge, TN 37830 